\title{
A Comparative Approach to Class Changing Derivational Affixes in English and Kurdish
}

\author{
Saza F. Abdulla1 ${ }^{1}$ Mohsin H. S. Qadir ${ }^{2}$ \\ ${ }^{1}$ Department of English language, College of Languages, University of Sulaimani, Kurdistan region, Iraq \\ ${ }^{2}$ Department of English language, College of Languages, University of Sulaimani, Kurdistan region, Iraq
}

\begin{abstract}
This paper is an analytical comparative morphological study of class changing of some of derivational affixes in Standard English and Central Kurdish from the standpoints of Generative Morphology. For the analysis, this work relies heavily on the identification of various class changing affixes between the two languages under study. The main goal is to identify the points of similarity and difference of class changing affixes that change the grammatical categories and the lexical meaning of the existing lexemes. The findings show that English and Kurdish are similar in the formation of nominal and adjectival affixes where certain lexemes can change the lexical categories and the meaning of the newly derived words. In English, in the formation of verbal affixes, a 'noun' and an 'adjective' can be converted into a 'verb' by adding certain prefixes and suffixes. While in Kurdish, no new lexemes can be formed from the root of the verb since the internal structure of the verbs in Kurdish works differently compared to English. In Kurdish, the suffix -a is attached to some cardinal numerals to derive a new noun, whereas in English, no newly derived nouns can be formed by numerals. English and Kurdish are different in the formation of new adverbial affixes. In English, certain adjectives and nouns can derive certain types of adverbs while in Kurdish these lexical categories are unable to derive adverbs by attaching certain derivational affixes.
\end{abstract}

KEY WORDS: Affixation, Base, Class Changing Affixes, Derivation, Multiple Affixation

\section{INTRODUCTION:}

In this paper, the morphological phenomenon of class changing derivational affixes in Standard English and Central Kurdish has been examined. The comparative approach has been used to analyze this morphological phenomenon in the two languages under scrutiny. The purpose of addressing this area is to conduct a comparative analysis of class changing derivational affixes to identify points of similarity and difference of those affixes that change the classes and the meanings of the new lexemes. The paper consists of five sections.

Koya University Journal of Humanities and Social Sciences (KUJHSS), Volume 4, Issue 1, 2021.

Received 07 Oct 2020; Accepted 23 Dec 2020,

Regular research paper: Published 30 Jun 2021

Corresponding author's e-mail: saza.fakhry@univsul.edu.iq

Copyright (02021. Saza F. Abdulla, Mohsin H. S. Qadir, this is an open access article distributed under the Creative Commons Attribution License.
Section one is an introduction to the topic. Section two involves research methodology where it includes the qualitative method of research, research questions, as well as procedures. Sections three and four present a theoretical framework of class changing in English and Kurdish where the derivational morphology in relation to the classification of class changing derivational affixes has been identified. This section is followed by the analysis and discussion of this morphological area. Section five aims at identifying the points of similarity and difference of class changing derivational affixes in both languages whereby the original contribution of this work has been presented followed by the main findings.

\section{METHODOLOGY AND RESEARCH QUESTIONS}

The selected method of this paper is a morphological comparative approach. The research questions of this paper are as follows:

1. Are class changing derivational affixes applicable to all the word classes in Standard English and Central 
Kurdish?

2. Are the two languages capable of deriving new lexemes by the process of multiple affixation?

To answer the above-mentioned questions, the following steps have been followed:

- Reviewing previous studies related to derivational morphology in English and Kurdish.

- discussing affixation and its types in both languages.

- grouping the most common derivational affixes in both languages to be analyzed in the comparative section of this paper.

- classifying the affixes into nominal, adjectival, verbal and adverbial.

- grouping those affixes in accordance with their types.

- examining those affixes that change classes in each separate section.

- analyzing the internal structure of the word classes (lexical categories) into their component parts.

- comparing class changing derivational affixes in the two languages by identifying points of similarity and difference according to the created groups in the previous two sections.

\section{CLASS CHANGING DERIVATIONAL AFFIXES IN STANDARD ENGLISH}

\subsection{Literature Review: Theoretical Framework}

According to Aronoff and Fudeman (2011, p.1), morphology in linguistics is "the mental system involved in word formation or it is the branch of linguistics that deals with words, their internal structure, and how they are formed". The basic element of a language is called a morpheme which is a meaningful linguistic unit that contains no smaller grammatical units (Yule 2010, p.67), as well as "the smallest linguistic pieces with a grammatical function" (Aronoff and Fudeman 2011, p.2).

Bauer (1983, p.22) classifies morphology into two parts as shown in the diagram below:

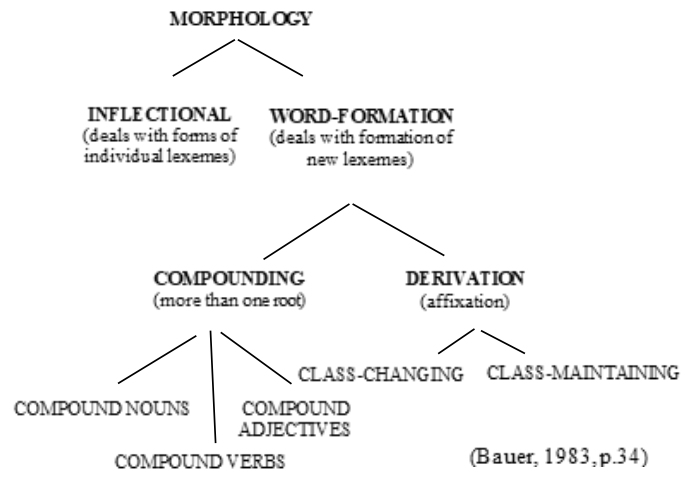

According to Bauer, morphology is divided into inflectional and word formation. Inflection "produces from the stem (or stems) of a given lexeme, as well as the word forms of that lexeme which occur in syntactically determined environments (Lyons 1977, pp. 521-2 in Bauer 1983, p. 34). Word formation is the formation of new lexemes that enlarge the vocabulary and therefore create new lexemes (Bauer 1983, p.33). This formation of creating new lexemes can be realized by a process called derivation by either changing the syntactic category or by adding new lexical meanings (or both) to a free or bound morpheme. For instance, the lexical item teach is a 'verb' that describes an action, when the morpheme -er 'one who is' is attached to it, a complex noun' teacher 'a person who teaches' will be formed. Similar examples like singer, dancer, baker, writer, etc.

As stated by O'Grady and Archibald (2016, p.100), words are extremely an important component in language as they carry meaning. Words in English can be classified into simple and complex (Akmajian et al 2001, p.15). A complex word can be divided into morphemes, which are defined by Brinton and Brinton (2010, p.82) as "the smallest meaningful units in a language." For example, gloriousness 'the state of having glory or being glorious' is a complex word which contains three morphemes: glory 'great honour', -ous 'full of, and -ness 'quality of'. As it is noticed here that glory is a free morpheme which can stand alone known also as the root which is the "indivisible central part of a complex word" (Bauer 1983, p.14). The morphemes -ous and $-n e s s$ are bound morphemes that cannot function as free-standing words (Radford et al. 2009, p.140) and should be attached to another lexical item. Thus, morphemes can be subdivided into free that can stand alone and bound which is "a meaningful grammatical unit that cannot occur alone" (Rowe and Levin 2016, p. 86).

In order to create newly derived words in a language, the process of affixation must be considered. According to Bauer (1983, p.90), and McCarthy (2002, p.20), affixes are bound morphemes that attach to "bases" which cannot stand on their own and have to be attached to other elements; and put in different places of the words such as, beginning, middle, or the end.

Affixation can be divided into prefixes and suffixes. Rowe and Levin state that "affixes attached before a root are called prefixes" (2016, p.86). For example, the suffixity 'state or quality of being' can be attached to the adjective curious to form the noun curiosity 'the desire to learn'. Suffixes can be defined as those morphemes that are attached to the root (or base) to create new lexemes having new forms and meanings by class changing category (Katamba 1993, p.5).

Table (1) below includes divisions of some English suffixes with their meanings and examples. 
TABLE 1

Some English Suffixes

\begin{tabular}{|c|c|c|}
\hline Suffix & Meaning & Examples \\
\hline $\begin{array}{l}\text {-al } \\
\text {-ance } \\
\text {-er/-or } \\
\text {-ful } \\
\text {-ion } \\
\text {-ise/-ize } \\
\text {-ity } \\
\text {-less } \\
\text {-ly } \\
\text {-ment } \\
\end{array}$ & $\begin{array}{l}\text { relation to } \\
\text { action } \\
\text { one who... } \\
\text { full of } \\
\text { action } \\
\text { to make } \\
\text { state } \\
\text { without } \\
\text { manner } \\
\text { result } \\
\end{array}$ & $\begin{array}{l}\text { elemental, spinal } \\
\text { disturbance, variance } \\
\text { reader, director } \\
\text { truthful, beautiful } \\
\text { action, dictation } \\
\text { neutralize, visualize } \\
\text { unity, punctuality } \\
\text { colourless, useless } \\
\text { beautifully, truly, } \\
\text { agreement, amusement }\end{array}$ \\
\hline
\end{tabular}

(Somathasan, 2018, p.3)

According to Katamba, derivational morphemes create new words by "changing the word class that a base belongs to" (1993, p.47) such as the addition of the suffix -ness 'the quality or state of' into the adjective sad to form the noun sadness, etc. In certain places, the derivational affixes can also cause "a major grammatical change" which means that "moving the base from oneword class into another as in -less" which changes a noun into an adjective" (Katamba 1993, p.48). For instance, when the suffix -less 'without, not having' is added to the noun home, it becomes an adjective homeless 'without home'.

As defined by Somathasan, class-changing derivational affixes are those "affixes which are added to an existing lexeme. As a result, a new lexeme is formed" (2018, pp.2-3) and the grammatical category of both lexemes changes. Dupanović (2019, p.76) mentions that there are 125 suffixes in English.

Leningrad's classification (1986, p.91) of suffixes can be summarized as follows.

Noun-forming suffixes: -ance/-ence 'act of, state of' (assistance, reference), -ant/-ent (confidant, correspondent), -dom 'sate of' (freedom), -ee 'a person who is the object' (employee), -er 'one who is' (writer), ion/-sion/-tion/-ation 'act or state of being' (rebellion, tension, creation, explanation), -ment 'refer to the action' (achievement), -ness 'state of; the quality of' (kindness), Adjective-forming suffixes : -able/-ible 'capable of, suitable for' (unbearable, audible); -al 'relating to' (rational); -ic 'relating to' (poetic), -ical 'relating to' (ethical); -ant/-ent 'doing or performing' (repentant, dependent); -ary 'relating to, connected with' (revolutionary); -ate 'showing; full of' (passionate); -ful 'full of' (delightful); -ish 'relating to' (reddish); -ive 'having a tendency or connection with' (active); -less 'not able to do something' (useless); -like 'similar to' (lifelike); -ly 'resembling' (manly); -ious 'characterized by' (adventurous); -some 'characterized by' (tiresome); y 'characterized by' (cloudy).

Verb-forming suffixes: -ate 'cause to become' (facilitate); -er (glimmer); -en 'cause to be' (shorten); -fy/ify 'to make or become' (terrify, solidify); -ize 'cause to become' (equalize); Adverb-forming suffixes: -ly 'in the manner of' (coldly); -ward/-wards 'in or toward a certain direction' (upward, northwards); -wise 'indicating direction or manner' (likewise).

Leningrad's classification of suffixes serves the goals of this paper in the identification of those affixes that contribute in changing class-membership of the newly derived forms.

Within affixation, multiple affixation has been taken into account by morphologists (Katamba \& Stonham 2006, p.54) which is defined as the method of forming complex words by adding several affixes to the root or base. For example, the lexical item nerve is a 'noun' which refers to "any of the long threads that carry messages between the brain and parts of the body". When the suffix -ous 'characterized by' is attached to it, it becomes nervous which is an 'adjective' and conveys the meaning of "being anxious about something". Two more derivative forms can also be created from the 'adjective' nervous: one is the 'adverb' nervously by suffixing -ly into it to convey of being "worried or frightened" and another is the 'noun' nervousness by adding the nominal suffix -ness into it to mean "the feeling of being anxious". What is worthy to mention is that multiple affixation must have a fixed order (Stageberg, 1981, p.91) when they are attached to the lexemes. Hence, the adjectival suffix -ous should be put first, then, the 'adverbial' -ly suffix and lastly, the nominal suffix - ness as introduced below:

$\begin{array}{lccc}\text { Noun } & \text { Adjective } & \text { Adverb } & \text { Noun } \\ \text { nerve } & \text { nervous } & \text { nervously } & \text { nervousness } \\ \text { glory } & \text { glorious } & \text { gloriously } & \text { gloriousness }\end{array}$

Similar suffixes can function in the same way such as the suffixes -ive 'having a tendency or connection with', when it is attached to a 'verb' impress 'to feel admiration', it becomes an 'adjective' impressive 'making someone feel admiration' in the same manner, the suffix -ly 'manner of' and -ness 'state of; the quality of' can also be added to the 'adjective' impressive to become an 'adverb' impressively 'in a way that making someone feel admiration' and impressiveness, respectively.

\subsection{Discussion and Analysis}

In English, class changing derivational affixes can be manifested by the process of affixation in which certain affixes can be added to certain words to change the grammatical categories and the meanings of 'nouns', 'verbs', 'adjectives' and 'adverbs'. Various affixes contribute in 'class-changing' derivational affixes by the process of multiple affixation. For instance, the 'noun' nation when the suffix - al 'relating to' is added to it, it becomes the 'adjective' national and at the same time, the 'adjective' national has the capacity to derive new lexical items including the 'adverb' nationally, the 'noun' 
nationality, the 'verb' nationalize, and the 'noun' nationalization. The 'verb' assert'state clearly and firmly' is converted into an 'adjective' assertive 'confident personality', as well as the 'adverb' assertively 'confidently'.

Here, the adjectival suffix -ive 'having a tendency or connection with' and the suffix -ly'in the manner of' changes the word class from a 'verb' into an 'adjective' and into an 'adverb', respectively. These suffixes are called class changing derivational suffixes as shown below:

Noun Adjective Adverb Noun Verb Noun

nation national nationallynationality nationalize nationalization

In English, class changing category depends on a variety of affixes as clarified below:

$\begin{array}{cccc}\text { Verb } & \text { Adjective } & \text { Adverb } & \text { Noun } \\ \text { assert } & \text { assertive } & \text { assertively } & \text { assertiveness }\end{array}$

\subsubsection{Nominal Affixes}

Certain lexical categories such as a 'verb 'and an 'adjective' can be converted into nouns by adding the following suffixes:

GROUP 1

verbs convert into nouns by adding the following suffixes:

\begin{tabular}{llll}
\hline \hline \multicolumn{1}{c}{ Verb } & Suffix & \multicolumn{1}{c}{ Meaning } & \multicolumn{1}{c}{ Noun } \\
\hline annoy & -ance & 'the action or state of' & annoyance \\
consult & -ant & 'doing or performing' & consultant \\
consultant & -ancy & 'doing or performing' & consultancy \\
sail & - or & 'one who' & sailor \\
depart & -ture & 'the action or result of' & departure \\
depress & - ion & 'act or state of being' & depression \\
dance & - er & 'one who is' & dancer \\
enquir & - ery & 'quality of' & enquiry \\
refer & $-e e$ & 'a person who is the object' & referee \\
achieve & - ment & 'refer to the action' & achievement \\
\hline \hline
\end{tabular}

As shown in the above group, the emboldened item consult is a 'verb', when the suffix -ant 'doing or performing' is attached to it, it becomes consultant which is a 'noun'. The changes occur in the grammatical category (verb into noun) and the meaning of the two lexemes, the former gives the meaning of obtaining "information or advice from a person, book, etc." and the latter refers to a person who provides "expert advice professionally" (Oxford Advanced Learner's Dictionary, 2015). The emboldened item depress is a 'verb', when the suffix -ion 'act or state of being' is attached to it, it becomes depression which is a 'noun'. The changes occur in the grammatical category of the 'verb depress into the noun and the meaning of the two lexemes, the former gives the meaning of someone who is depressed and the latter refers to a medical condition of feeling sad. In certain cases, certain suffixes convey the same meanings, for instance, the suffixes -ion, -tion, -ation and -ition 'act or state of being' when they are attached to the 'verbs' celebrate, fascinate, examine and juxtapose; they can derive the nouns celebration, fascination, examination and juxtaposition. The suffixes -ance and -ence 'the action or state of ' when they are attached to the verbs annoy and depend, the nouns annoyance and dependence are formed. When the suffixes - ancy and -ency (the state or quality of) are attached to the 'verbs' consult and delicate, the nouns consultancy and dependency are formed. It can be concluded that the suffixes -ance/-ence,-ant,-cy, -or, ion/-sion/-tion/-ation, -ee, -ancy, -ure,-er,-ery, -ment are all class changing suffixes that convert verbs into nouns.

\section{GROUP 2}

Adjectives convert into nouns by adding the following suffixes:

\begin{tabular}{llll}
\hline \multicolumn{1}{r}{ Verb } & Suffix & \multicolumn{1}{c}{ Meaning } & \multicolumn{1}{c}{ Noun } \\
\hline sad & - ness & 'the quality, state or character of' & sadness \\
fool & - ish & 'having the nature of' & foolish \\
national & - ism & 'the state or quality of & nationalism \\
brilliant & -ance & 'act of, state of' & brilliance \\
wise & - dom & 'state of being' & wisdom \\
private & - cy & 'the state or quality of' & privacy \\
abundant & $-c e$ & 'act of being' & abundance \\
social & $-i s t$ & 'describe the actions or occupations' & socialist \\
absent & $-e e$ & 'a person who is the object' & absentee \\
\hline \hline
\end{tabular}

The above emboldened lexical item brilliant is an 'adjective' that refers to a person who is extremely "clever". When the suffix -ance 'act of, state of' is attached to it, it becomes a noun brilliance. It changes the grammatical category of the existing lexeme (from a noun into an adjective). This new word makes a minor change of meaning "the quality of being extremely [...] intelligent or skillful".

The above emboldened lexical item private 'personal not public' is an 'adjective'. When the suffix -cy (the state or quality of' is attached to it) becomes a noun privacy 'the state of being private". The grammatical category of the adjective private has been changed into a noun privacy. Thus, the suffixes -ance -ness, -ish, -cy, ist,-acy, -ism, -dom, -ce,-ee are all class-changing derivational suffixes that convert adjectives into nouns.

\subsubsection{Adjectival Affixes}

Adjectival affixes are used to form adjectives from other lexical categories. The following groups include those affixes that change the grammatical categories and the lexical meaning of the new derived forms:

\section{GROUP 1}

Nouns convert into adjectives by adding the following suffixes:

\begin{tabular}{lcll}
\hline \hline \multicolumn{1}{c}{ Verb } & Suffix & \multicolumn{1}{c}{ Meaning } & \multicolumn{1}{c}{ Noun } \\
\hline profession & - al & 'relating to' & professional \\
passion & - ate & 'full of or having the quality of' & \\
cloud & $-y$ & 'characterized by' & cloudy \\
danger & - ous & 'full of' & dangerous \\
fashion & - able & 'capable of' & fashionable \\
attract & $-i v e$ & 'having the nature of' & attractive \\
friend & $-l y$ & 'resembling' & friendly \\
revolution & - ary & 'connected with' & revolutionary \\
child & $-i s h$ & 'relating to' & childish \\
pain & $-f u l$ & 'full of' & painful \\
academy & $-i c$ & 'connected with' & academic \\
\hline \hline
\end{tabular}


In English, the lexical item profession is a 'noun' when the suffix -al 'relating to' is attached to it, it becomes professional which is an 'adjective'. Hence, the grammatical category is converted from a noun profession into an adjective professional and the meaning of the existing lexeme "a type of job that needs special training or skill" has been changed to a "well trained and extremely skilled' person (Oxford Advanced Learner's Dictionary, 2015). Moreover, the lexical item passion is a 'noun' when the suffix -ate 'showing; full of' is attached to it, it becomes passionate which is an 'adjective', the meaning of the original lexeme is a "strong feeling of [...] enthusiasm" (Oxford Advanced Learner's Dictionary, 2015) has been shifted into 'a person who is enthusiastic about something'. The suffixes $-a l,-y,-$ able, -ly, -ish, -ic, -ate, -ous, -ive, -ary, -ful are class changing suffixes that convert nouns into adjectives.

\section{GROUP 2}

Nouns convert into adjectives by adding the following suffixes:

\begin{tabular}{llll}
\hline \multicolumn{1}{c}{ Verb } & Suffix & \multicolumn{1}{c}{ Meaning } & \multicolumn{1}{c}{ Adjective } \\
\hline assert & - ive & 'connection with' & assertive \\
achieve & -able & 'having the quality of' & achievable \\
reduce & - ible & 'having the quality of' & reducible \\
differ & - ent & 'doing or performing' & different \\
bore & - dom & 'the condition of state of' & boredom \\
anger & $-y$ & 'characterized by' & angery \\
end & - less & 'not able to do something' & endless \\
class & $-i c$ & 'relating to' & classic \\
sense & - ory & 'involving the action concerned' & sensory \\
\hline \hline
\end{tabular}

The emboldened lexical item achieve is a 'verb' which is connected with fulfilling a "particular goal". When the suffix -able 'having the quality of' is attached to it, it becomes achievable which is an 'adjective' that refers to a person who makes considerable efforts. The newly derived lexeme and the original one has different meanings and belong to two different grammatical categories. The suffixes - ive, able, -ible, -, -dom, -less, ory $-a b l e,-e n t,-y,-i c$ are all class changing suffixes that convert verbs into adjectives.

\subsubsection{Verbal Affixes}

Verbal affixes are used to form verbs from other lexical categories listed in the following groups:

$$
\text { GROUP } 1
$$

Nouns convert into verbs by adding the following affixes:

\begin{tabular}{llll}
\hline \hline Noun & Suffix & \multicolumn{1}{c}{ Meaning } & \multicolumn{1}{c}{ Verb } \\
\hline beauty & - ify & 'to make or become' & beautify \\
apology & - ize & 'cause to become' & apologize \\
\hline \hline
\end{tabular}

The above emboldened lexical item apology is a 'noun' that means "saying sorry for something that causes a problem". When the suffix -ize 'cause to become' is attached to it, it becomes apologize which is a 'verb'. Hence, the grammatical categories of the new lexeme has been changed while the meaning of the new lexeme has not considerably been changed since the 'verb' apologize means "saying sorry for doing something wrong", its grammatical categories have also been converted. The following prefixes are attached to a 'noun' to form a 'verb'.

\begin{tabular}{|c|c|c|c|}
\hline Prefix & Meaning & Noun & Verb \\
\hline be- & $\begin{array}{l}\text { 'treat somebody or } \\
\text { something as' }\end{array}$ & friend & befriend \\
\hline en- & 'to cause to be' & title & entitle \\
\hline
\end{tabular}

The same interpretation could be applied to the emboldened lexical item title "the name of a book, poem, painting, piece of music", which is a 'noun'. When the prefix en- 'to cause to be' is added to it, the 'verb' entitle 'to give a right or claim' is formed. The suffixes -ify, -ize and the prefix be-, en- are all class-changing derivational affixes that convert nouns into verbs.

GROUP 2

Adjectives convert into verbs by adding the following affixes:

\begin{tabular}{lccl}
\hline \hline Adjective & Suffix & Meaning & Verb \\
\hline soft & -en & 'to make' & soften \\
\hline real & -ize & 'cause to become' & realize \\
strong & - th & 'the action or process of' & strength \\
\hline \hline
\end{tabular}

The above emboldened lexical item soft is an 'adjective' which means "smooth and pleasant to touch". When the suffix - en 'to make' is attached to it, it becomes soften which is a 'verb' that means making "something softer" (Oxford Advanced Learner's Dictionary, 2015). More examples of -en suffix can be seen in words such as weaken, shorten, lighten, blacken, sharpen, loosen, etc.

\begin{tabular}{cccc}
\hline \hline Prefix & Meaning & Adjective & Verb \\
\hline $\boldsymbol{e n}$ - & 'to cause to be & large & enlarge \\
\hline \hline
\end{tabular}

The lexical item large is an adjective, when the prefix en- 'to cause to be' is attached to it, it becomes enlarge which is a 'verb' that means "to make something bigger" (Oxford Advanced Learner's Dictionary, 2015).

\subsubsection{Adverbial Affixes}

Adverbial affixes are concerned with forming adverbs from other lexical categories. The following groups include those affixes that change the grammatical categories and the lexical meaning of the original words.

GROUP 1

Nouns convert into adverbs by the following derivational affixes:

\begin{tabular}{|c|c|c|c|}
\hline Noun & Suffix & Meaning & Verb \\
\hline river & -ward & 'in or toward a certain direction' & riverward \\
\hline heaver & - wards & 'in or toward a certain direction' & heavenwards \\
\hline clock & -wise & 'indicating direction or manner' & clockwise \\
\hline length & -ways & 'in the direction of' & lengthways \\
\hline
\end{tabular}




\begin{tabular}{cccc}
\hline \hline Prefix & Meaning & Adjective & Verb \\
\hline$a-$ & 'not, without' & shore & ashore \\
\hline \hline
\end{tabular}

The emboldened lexical item length is a 'noun' which refers to "the size or measurement of something from one end to the other". When the suffix -ways "indicating direction or manner' is attached to it, it becomes lengthways which is an 'adverb' that expresses "the same direction as the longest side of something" (Oxford Advanced Learner's Dictionary, 2015).

GROUP 2

Adjectives convert into adverbs by affixing -ly ‘as below:

\begin{tabular}{lcl}
\hline \hline Adjective & Suffix & Adverbs \\
\hline brave, & - ly & bravely \\
constant, honest, & 'in the way & constantly, honestly, \\
persuasive & mentioned' & persuasively \\
\hline \hline
\end{tabular}

Besides, the emboldened lexical items brave is an 'adjective' that means 'courageous and valiant'. When the suffix -ly 'in the way mentioned' is attached to it, it becomes bravely which is an 'adverb' which means 'courageously'.

\subsection{Conclusion}

In English, the following conclusions are drawn from the analysis of this section:

1. Class changing derivational affixes can be represented by adding certain affixes to the existing lexemes to form new lexical items.

2. English language can form a variety of lexical items by the process of multiple affixation.

3. Class changing derivational affixes can be represented by adding certain affixes to the existing lexemes to form new lexical items.

4. Class changing category has two functions: firstly, new meanings will be formed and secondly, changing the grammatical category of the original lexeme as explained below:

a. Nominal affixes can be formed by attaching a suffix to a 'verb' and an 'adjective' to form new 'nouns',

b. Adjectival affixes can be formed by attaching a suffix to a 'noun' and a 'verb' to form new 'adjectives'.

c. Verbal affixes can be formed by adding a prefix to a 'noun' and an 'adjective', as well as a suffix to a 'noun' and an 'adjective' to derive new 'verbs'.

d. Adverbial affixes can be formed by attaching a prefix to a 'noun', as well as a suffix to an 'adjective' to derive adverbs. Thus, a 'verb' cannot be converted into an 'adverb' to derive an 'adverb'

e. The - en suffix can be added to an 'adjective' and to a 'noun' to form a new derived word, namely a 'verb'.

\section{CLASS CHANGING DERIVATIONAL AFFIXES IN CENTRAL KURDISH}

\subsection{Literature Review: Theoretical Framework}

In Central Kurdish, morphology is the study of the internal structure of words and the changes that occur within the words (Marif 2014, p. 6). Word formation is the formation of new lexemes that extend the lexical categories of the new lexeme (Clark et al 1986, p.27). According to Marif (2014; [1977, p.21]), word formation is the way words are formed, its componential parts, and its structural groups. Word formation deals with the formation of new lexemes for the production of thousands of newly derived words (Bakir and Awl 2012, p. 873).

In Kurdish, derivation is the process of forming new words by adding a prefix and a suffix, or both together. For instance, the suffix -ga 'place' can be attached to the 'noun' ka:r 'work' to form the new 'noun' ka:rga 'factory'. The meaning of the existing word will change into a totally different meaning.

The formation of new lexemes will depend on the process of derivation which is a part of a derivational morphology by either converting the grammatical category of the new lexemes or adding new meanings. In order to understand the way Kurdish derivational morphemes work, the following notions must be considered.

Root is the core of the words that are not divisible into smaller parts and carries the meaning of the words (Marif 2014 [1977: p. 30]). Morphemes can be defined as the words or a part of words that carry meaning, as well as they are the smallest meaningful units (Fattah and Qadir 2006, p. 8). For instance, the lexeme pa:rez 'keep' is the verbal root, when the suffix $-a r$ is attached to it, the new lexeme pa:rezar 'lawyer' is formed which is a 'noun'. The grammatical category and the meaning of the new lexeme have been changed from a 'verb' pa:rez into a 'noun' pa:rezar 'lawyer'. Morphemes can be divided into free and bound. A free morpheme is a morpheme that stands as a free word by its own (Bakir and Awl 2012 p. 875). It has a complete and a lexical meaning such as, the 'noun' bard 'stone' and the 'adjective' jwa:n 'beautiful'. When the bound morphemes ala: $n$ and $i$ are attached to them, they become the 'adjectives' bardala:n 'a place covered with stones' and jwa:ni 'beauty' (Awl 2010, p. 314). Bound morphemes are those morphemes that cannot stand alone and must be attached to another morpheme and can only appear as a part of another word" (Hamawandy 2012, p.3). For instance, the 'noun' hunar 'art' when the bound morpheme $-i$ is attached to it, it becomes the 'adjective' hunari 'artistic'.

Muhammad (2011, p. 26) states that the derivational words include those words that contain a free morpheme, as well as an additional item that does not 
have a separate meaning by its own. It has a meaning when affixes are attached to it. For instance, the suffix $-a$ when attached to a numeral čil 'forty', it becomes čila to mean 'a person's forties after his death' and also to mean 'the middle of summer and winter seasons'.

According to Bakir and Awl (2012, p. 874), derivational nouns are formed by the process of affixation that combines (root/base + derivational affixes) to derive new lexical categories and meanings as summarized below:

\begin{tabular}{cccc}
\hline \hline $\begin{array}{c}\text { Derivational } \\
\text { Prefix }\end{array}$ & Root/Base & $\begin{array}{c}\text { Derivational } \\
\text { Suffix }\end{array}$ & $\begin{array}{c}\text { Derivational } \\
\text { Noun }\end{array}$ \\
\hline $\boldsymbol{p e}+$ & wi:st 'need' & pewi:st & 'need' \\
$f r+$ & -oka & froka & 'airplane' \\
\hline \hline
\end{tabular}

In Kurdish, affixation is a process of word formation that deals with driving new words by attaching prefixes and suffixes into free forms and bound forms. According to Awl (2010, p. 316), prefixes are bound morphemes attached before a root such as the prefixes pe- 'an instrument' in pexaf 'bed-clothing', hal- 'up' in haldačim 'become angry', da:- 'down' in da:bazi:n, 'step down' da:'doing or making' in daxawet 'will sleep'.

Hamawand and Fattah (2014, pp. 37-49) mention some prefixes that "derive new words" including "beand haw-". The prefix be- is attached to "nouns to form new adjectives "denoting abundance" "'. When it is added to "an abstract nominal root" hez 'strength', it forms a "qualitative adjective" bahez 'strong'. Moreover, the prefix $\boldsymbol{b} \boldsymbol{e}$ - can also be attached to an 'abstract noun' to form adverbs of manner 'denoting the way of performing an action". For example, the 'adverb' baxaerayi 'quickly' is formed from the 'noun' xerayi 'quickness' by attaching the prefix be- "doing an action in the manner mentioned" (Hamawand and Fattah 2014, p. 45) to form the 'adverb' baxerai. The same prefix becan also be attached to "nominal roots to derive 'adjectives' expressing equal status" such as "the adjective hawsis:n 'counterpart' is formed from ŝan 'shoulder' and the prefix haw- 'having equal status'" (Marif 2014, p. 46). For the same suffix be- 'abundance', Dizayee (2012, pp. 59-60) also mentions that when this prefix is added to the 'verbal root kul 'heat', the 'adjective bakul 'enthusiastic' is formed. Dizayee also states that when the suffix -mand 'having' is attached to the 'verbal root' hoš, the 'adjective' hošmand 'thoughtful' is formed. While Baban (2008, pp.136-137) mentions three prefixes such as hal- 'up', da: - 'down', ra- 'a horizontal position' when they are attached to the root of the 'verb' $g r$ from the infinitive grtin 'catch', the new 'nouns' halgir 'carrier', da:gr 'get down' and ra:gr 'the dean' are formed which convey different meanings.

Affixation also includes suffixes which are bound morphemes attached after a root. The lexical category of the root or a base change when the derivational suffixes are attached to it. The suffix $i$ : has the ability to change a word from one class category to another (Marif 1977, p.38). When it is attached to the adjectives kwer 'blind', drež 'long', jwa:n 'beautiful', the 'nouns' kweri 'blindness' dreži: 'length', jwani: 'beauty' will be formed. On the other hand, the suffix $\boldsymbol{- n}$ when it is attached to 'nouns': wrg 'stomach', šarm 'shy', čilk 'dirty spots', the 'adjectives\wrgin, 'big stomache' šarmin 'a shy person', čilkin 'a dirty person' are formed (Awl 2010, pp. 317318).

Moreover, Marif (2014, p.16) states that when the suffix -a:na is attached to a 'noun' pya:w'man' it changes the existing lexeme from a 'noun' into an 'adjective' and an 'adverb' as explained in the following sentences:

- Jili: pya:wana girana. 'men's clothes are expensive'.

- Azad pya:wana darwat. 'Azad walks manly'.

The suffix -awi is attached to a 'noun' to form the 'adjective' such as xolawai 'soiled with dust'. This suffix means "affected by, soiled/ tainted" (The Sharezoor Kurdish-English Dictionary, 2000, pp. 35-36). When the suffix $-\check{c} a$ is attached to a 'noun' like hatm 'orphan', it changes its category from a 'noun' into an 'adjective' hatmča 'small orphan'. Dizayee (2012, pp. 59-60) also mentions that the suffix -mand when it is attached to a 'noun' hoš, the 'adjective' hošmand 'thoughtful' is formed.

The above-mentioned prefixes and suffixes that Kurdish morphologists classify contribute in the category of class-changing derivational affixes that can change the grammatical category and the lexical meaning of the newly derived words from the existing lexemes (Bakir and Awl 2012, p. 875).

Derivational morphemes create new words by "changing the meaning and the grammatical categories of the base to which they are attached". For instance, the two lexical items ya:sa 'law' and ya:sa:i: 'legal' are a 'noun', and an 'adjective', respectively. The former is the root while the latter is the newly derived one by suffixing $i$ : into it, it become yasa:i: and etc. which convey two different meanings, as well as different syntactic categories.

To identify the Kurdish lexical categories, it is important to know that Kurdish word classes consist of 'nouns', 'pronouns', 'adjectives', 'numerals', 'verbs' and 'adverbs' (Marif 2014, p.14). In Kurdish, words can be classified into simple and complex (Muhammad 2011, p.27). A complex word can be formed by a verbal root and a prefix for instance, the base da: $\boldsymbol{n}$ when the prefix hal- 'up' is attached to it, it becomes a 'verb' halda:n 'throw'. The suffix -awa can also be attached to the 'verb' halda:n 'throw' to form halda:nawa 'to uncover something' which 'is a complex word containing three morphemes: hal, -da:n and -awa. The prefix hal- and the suffix -awa are bound morphemes that cannot function as free-standing words (Muhammad 2011, p.26) and should be attached to another lexical item. When 
two or more affixes are attached to a word, multiple affixation occurs. In the formation of Kurdish verbs, some of the verbal roots like lariz 'shiver', tris 'fear', pris 'enquire' can form new 'adjectives' such as larzok 'shivering', trisnok 'coward', prsyar 'enquiry', etc. In this case, they lose their free identity (Fattah 1989, p. 45). Due to that Kurdish language has its own morphological rules, verbs must contain the following components: root, tense, person and number (Awl 2010, p.338).

In order to create new words from 'verbs', the root and the stem of the 'verbs' must be taken into account. For more clarification about this point, two instances need to be taken: first, the root of the 'verb' nu:si:n 'writing' is nu:s 'write, when the suffix -ar is attached to it, it becomes the 'noun' nu:sar 'writer'. In this case, a new lexeme 'noun' is formed because of having the root nu:s 'write' of the 'verb'. In another instance, the root of the 'verb' $k r$ becomes a stem when the tense marker $-i$ 'quality or state' (McCarus 1957, p.90) is attached to it to become $k r i$ 's/he bought', when the suffix -ar is attached to it, it becomes krya:r 'buyer' which is a new 'noun'. As shown below:

$k r($ root $)+i$ (stem) + ar (suffix) $=$ kryar 'buyer

$z a n($ root $)+i=z a: n i$ (stem) + -yar= zanya:r 'scientist'

\subsection{Discussion and Analysis}

In Kurdish, class-changing derivational affixes include prefixes and suffixes which are attached to an existing word to form a new word with the difference in the grammatical categories and the meanings of both words. For example, the word tris 'fear' is a root of the 'verb' tirsa:n 'be afraid', when the suffix - na:k is added to it, the 'adjective' tirsna:k 'fearful' is formed. The 'verb' tirs 'fear' and the 'adjective' tirsna: $k$ 'fearful' are two different words that belong to different classes. At the same time, from the 'adjective' tirsna:k 'fearful' a new lexical item, namely a 'noun' can be formed by suffixing $i$ : into the 'adjective' tirsna:k to form tirsna:ki 'the fear'. Here, the nominal suffix $-i$ : 'quality or state' can change the word class from an 'adjective' into a 'noun'. These suffixes $a: k$ and $i$ : are called class changing derivational suffixes as shown below:

\begin{tabular}{ccccc}
\hline \hline Verb & Suffix & Adjective & Suffix & Abstract Noun \\
\hline tirs & -na:k & tirsna:k & $-i:$ & tirsna:ki: \\
'fear' & 'quality of & 'fearful' & 'qualityorstate' & 'the fear' \\
\hline \hline
\end{tabular}

The above two-mentioned examples are instances of multiple affixation in Kurdish. Class changing derivational affixes can be summarized below:

\subsubsection{Nominal Affixes}

In Kurdish, a number of affixes create nouns which can change the syntactic categories and the meaning of the existing words. These can be as follows:
GROUP 1

Verbs convert into nouns by adding the following suffixes:

\begin{tabular}{|c|c|c|c|c|c|}
\hline Verb & Meaning & Suffix & Meaning & Noun & Meaning \\
\hline$\overline{n u: s}$ & 'write' & $a r$ & 'onewho' & nu:sar & 'writer' \\
\hline fer & 'teach' & $g a$ & 'place' & ferga & $\begin{array}{l}\text { 'learning } \\
\text { place' }\end{array}$ \\
\hline $\begin{array}{l}\text { žmer } \\
\text { gar }\end{array}$ & $\begin{array}{l}\text { 'account' } \\
\text { 'search' }\end{array}$ & $\begin{array}{l}y a: r \\
o k\end{array}$ & $\begin{array}{l}\text { 'one who' } \\
\text { 'characterized by }\end{array}$ & $\begin{array}{l}\text { žmerya:r } \\
\text { 'garok }\end{array}$ & $\begin{array}{l}\text { 'accountant' } \\
\text { 'wanderer' }\end{array}$ \\
\hline$n i \check{s} t$ & $\begin{array}{l}\text { 'settle } \\
\text { down' }\end{array}$ & ma:n & 'possession' & nimšti:ma:n & 'homeland' \\
\hline garm & 'hot' & $a:$ & $\begin{array}{l}\text { 'quality or } \\
\text { condition' }\end{array}$ & garma: & 'heat' \\
\hline xwa:rd & 'to eat' & $u:$ & 'having' & xwa:rdu: & 'having eaten' \\
\hline
\end{tabular}

As shown in the above group, the emboldened item žmer 'account' is a 'verbal root' when the suffix -ya:r is attached to it, it becomes žmerya:r 'accountant' which is a 'noun'. Two changes occur: one in the grammatical category of the 'verb' žmer 'account' and the 'noun' žmeryar and two in the lexical meanings of the two words. All the suffixes listed in the above-mentioned group, namely -ar, -ga, ya:r, -ok, -ma:n, -a: and -u: are class-changing derivational suffixes that convert verbs into nouns. The following prefixes can be attached to the verbs to form nouns:

\begin{tabular}{|c|c|c|c|c|}
\hline Prefix & Meaning & Verbal Root & Noun & Meaning \\
\hline $\begin{array}{l}\text { bi- } \\
b a- \\
p e- \\
r a: \\
d a-\end{array}$ & $\begin{array}{c}\text { 'one who' } \\
\text { 'quality of' } \\
\text { 'an instrument } \\
\text { 'a horizontal position' } \\
\text { 'down' }\end{array}$ & $\begin{array}{c}\boldsymbol{k u}: \check{z} \text { 'murder' } \\
\text { čež 'taste' } \\
\text { xaf 'sleep' } \\
\text { xistin 'to fall' } \\
\text { știin 'get washed' }\end{array}$ & $\begin{array}{l}\text { biku: ž } \\
\text { bačež } \\
\text { pexaf } \\
\text { raxistin } \\
\text { dašitin }\end{array}$ & $\begin{array}{c}\text { 'murderer' } \\
\text { 'tasty' } \\
\text { 'bed-clothing' } \\
\text { 'lay out' } \\
\text { 'lampoon' }\end{array}$ \\
\hline
\end{tabular}

The emboldened item $k u: \check{z}$ 'murder' is a 'verbal root' when the prefix $\boldsymbol{b i}$ - is attached to it, it becomes biku: $\check{z}$ 'murderer'. The changes occur in the grammatical category and then lexical meaning of the 'verb' $k u: \check{z}$ 'murder' which is "the process of killing someone" and the noun biku:žz 'murderer' which refers to the person who has killed someone.

\section{GROUP 2}

Adjectives can convert into nouns by adding the following affixes:

\begin{tabular}{|c|c|c|c|c|c|}
\hline Adjective & Meaning & Suffix & Meaning & Noun & Meaning \\
\hline tinu: & 'thirsty' & $e t i$ & 'state of' & tinueti & 'thirst' \\
\hline $\begin{array}{l}\text { hati:m } \\
\text { garm }\end{array}$ & $\begin{array}{l}\text { 'orpha' } \\
\text { 'hot' }\end{array}$ & $\begin{array}{l}\check{c} a \\
o k a\end{array}$ & $\begin{array}{c}\text { 'smallness' } \\
\text { 'characterized by' }\end{array}$ & $\begin{array}{l}\text { hati:mča } \\
\text { garmoka }\end{array}$ & $\begin{array}{l}\text { 'small orphan' } \\
\text { 'heating' }\end{array}$ \\
\hline narm & 'soft' & ala:n & 'a quality of' & narmala:n & 'softening' \\
\hline$\check{c} a k$ & 'virtuous' & , $\quad a$ & 'a quality of' & $\check{c} a k a$ & 'virtue' \\
\hline spi: & 'white' & $a y i$ & 'quality of' & spiayi & 'whitened' \\
\hline zirak & 'clever' & $i:$ & 'quality or state' & ziraki: & 'cleverness' \\
\hline šarm & 'shy' & in & 'characterized by' & šarmin & 'shyness' \\
\hline
\end{tabular}

The above emboldened lexical item zirak 'clever' is an 'adjective'. When the suffix - $i$ : 'quality or state' is attached to it, it becomes a 'noun' ziraki: 'cleverness'. The grammatical category of the existing 'adjective' zirak is converted into a 'noun' ziraki. 
GROUP 3

Numerals can be converted into a 'noun' by adding the following suffixes:

\begin{tabular}{cccc}
\hline \hline Numerals & Suffix & Noun & Meaning \\
\hline sad 'one-hundred' & $-a$ & sada & \multicolumn{2}{c}{$\begin{array}{c}\text { a century' } \\
\text { čil 'forty' }\end{array}$} & $-a$ & čila & $\begin{array}{l}\text { a dead person's fortieth', 'middle of } \\
\text { summar' }\end{array}$ \\
\hline \hline
\end{tabular}

In Kurdish, the suffix $-\boldsymbol{a}$ can be attached to some 'cardinal numerals' including čil 'forty', and sad 'onehundred' to create 'nouns' čila 'a dead person's fortieth' and sada 'a century'. The original words have been changed from the numerals (sad, čil) to nouns (sada, čila) and the meanings of the existing numerals have totally been changed when the suffixes are attached to them.

\subsubsection{Adjectival Affixes}

GROUP 1

Nouns can be converted into adjectives by adding the following suffixes:

\begin{tabular}{|c|c|c|c|c|c|}
\hline Noun & Meaning & Suffix & Meaning & Adjective & Meaning \\
\hline hawr & 'cloud' & $-a w i$ & 'covered with' & hawra:wi & 'cloudy' \\
\hline žin & 'woman' & $-a: n i$ & 'quality of having' & žina:ni & 'womanly' \\
\hline$k i \check{c}$ & 'girl' & $-a: n a$ & 'quality of having' & kiča:na & 'girly' \\
\hline$d a \check{s} t$ & 'plain' & $-a k i$ & 'quality of having', & daštaki & 'rural' \\
\hline$a: g r$ & 'fire' & $-i: n$ & 'characterized by' & agri:n & 'fiery' \\
\hline pirx & 'snore' & $-i n$ & 'characterized by' & pirxin & 'snooring' \\
\hline karama & profession & $-a y i$ & 'quality of having' & karamayi: & 'professional' \\
\hline
\end{tabular}

In Kurdish, the lexical item hawr 'cloud' is a 'noun' when the suffix -awi 'covered with' is attached to it, it becomes hawra:wi 'cloudy' which is an 'adjective'. Hence, the grammatical category is converted from a 'noun' hawr into an 'adjective' hawrawi: and the meaning of the existing lexeme hawr 'cloud' has been changed into hawrawi: 'cloudy'. Another example of adjectival suffixes can be seen in the lexical item kič 'girl' which is a 'noun' when the suffix -a:na 'quality of having' is attached to it, it becomes kiča:na 'girly' which is an 'adjective', the meaning of the original lexeme kič 'girl' has been changed into kiča:na 'girly'. The following prefixes are attached to a 'noun' to form an 'adjective':

\begin{tabular}{|c|c|c|c|c|}
\hline Prefix & Meaning & Meaning & Adjective & Meaning \\
\hline $\begin{array}{l}b a- \\
b a- \\
b a- \\
\end{array}$ & $\begin{array}{l}\text { 'abundance' hez } \\
\text { 'abundance' ta:m } \\
\text { 'abundance' jarg }\end{array}$ & $\begin{array}{l}\text { 'strength' } \\
\text { 'taste' } \\
\text { 'liver' } \\
\end{array}$ & $\begin{array}{c}\text { bahez } \\
\text { bata:m } \\
\text { bajarg }\end{array}$ & $\begin{array}{c}\text { 'strong' } \\
\text { 'tasty' } \\
\text { 'fortitudinous' }\end{array}$ \\
\hline
\end{tabular}

The above emboldened lexical item ta:m 'taste' is an 'noun'. When the prefix $\boldsymbol{b a}$ - 'abundance' is attached to it, it becomes bata:m 'tasty' which is an 'adjective'. The grammatical category and the meaning of the existing 'noun' have been changed from ta:m 'taste' into bata:m 'tasty' which means that the prefix $\boldsymbol{b} \boldsymbol{a}$ - is a class changing derivational prefix since it changes the existing lexeme from a 'noun' into an 'adjective'.

\section{GROUP 2}

Verbs convert into adjectives by adding the following suffixes:

\begin{tabular}{cccccc}
\hline \hline Verb & Meaning & Suffix & Meaning & Adjective & Meaning \\
\hline ku:ž & 'kill' & $-n d a$ & 'characterized by' ku: šnda & 'fatal' \\
larz & 'shiver' & - ok & 'characterized by' & larzok & 'shivering' \\
\hline \hline
\end{tabular}

The emboldened lexical item larz 'shiver' is a root of the 'verb'. When the suffix -ok 'characterized by' is attached to it, it becomes larzok 'shivering' which is an 'adjective'. The meaning of the original lexeme larz 'shiver' has been changed into larzok 'shivering'.

In the following lexemes, the prefix $\boldsymbol{b a}$ - is attached into a 'verb' to form an 'adjective':

\begin{tabular}{cccccc}
\hline \hline Prefix & Meaning & Verb & Meaning & Adjective & Meaning \\
\hline $\boldsymbol{b a} \boldsymbol{a}$ - & abundance & čež & taste & bačež & tasty \\
$b \boldsymbol{a}$ - & abundance & $\mathrm{kul}$ & boil & bakul & boiling \\
\hline \hline
\end{tabular}

The prefix $\boldsymbol{b} \boldsymbol{a}$ - 'abundance' when it is attached to the 'verb' čež 'taste' it becomes an 'adjective' bačež 'tasty'. Similarly, this prefix can also be attached to the 'verb' $k u l$ 'boil' to become bakul 'boiling' which is an 'adjective'. The grammatical category and the meaning of the existing lexemes in both examples have been changed from 'verbs' into 'adjectives'. All the affixes discussed in this section are class-changing derivational suffixes.

\subsection{Conclusion}

In Kurdish, the following conclusions are drawn from the analysis of this section:

1. Class changing derivational affixes rely heavily on certain affixes that are attached to certain lexemes to form newly derived lexemes.

2. Kurdish language can create some lexical items by the process called multiple affixation.

3. Class changing category has two functions: firstly, new meanings will be created and secondly it changes the grammatical categories of the original lexemes as explained below:

a. Nominal affixes can be formed by attaching a suffix into a 'verb' and an 'adjective', a prefix into an 'adjective' to form a new 'noun', as well as a suffix - $\boldsymbol{a}$ into 'cardinal numerals' čil 'forty', and sad 'one-hundred' to form new 'nouns' čila 'a dead person's fortieth' and sada 'a century'.

b. Adjectival affixes can be formed by attaching a suffix into a 'noun' and a 'verb', as well as a prefix into a 'verb' to form new 'adjectives'. 
c. Verbal and adverbial affixes cannot change the lexical categories and the meaning of the existing lexemes in Kurdish.

d. The prefix $\boldsymbol{b} \boldsymbol{a}$ - on the one hand can be attached to a 'verb' čež 'taste' to form a 'noun' bačež 'tastey' and it can be attached to the 'noun' ta:m 'taste' to create bata:m 'tasty on the other hand.

\section{A COMPARATIVE APPROACH TO CLASS CHANGING IN STANDARD ENGLISH AND CENTRAL KURDISH}

The goal of this section is to identify points of similarity and difference of class changing derivational affixes in Standard English and Central Kurdish.

\subsection{Points of Similarity and Difference}

In English and Kurdish, class changing derivational affixes can be represented by adding certain affixes to the existing lexemes to form new lexical items. In Standard English and Central Kurdish, a large number of new words with new grammatical categories can be formed by the process called multiple affixation. However, the range of Kurdish examples is lesser than in English. In English, it is possible to add more than one affix to the lexical categories. For instance, the lexical item nation is a 'noun' when the suffix -al is attached to it, the following lexical categories are formed: the adjective national, the adverb nationally, the 'noun' nationality, the 'noun' nationalism, the 'verb' nationalize, as well as the 'noun' nationalization. The suffixes $-a l,-l y$, ity, -ism, -ize and -ation are class changing derivational suffixes that can be added by a process of multiple affixation. In Kurdish, the suffix -na:k 'quality of' when it is attached to the 'noun' $x a m$ 'feeling anxious' and the 'verb' tris 'fear' the 'adjectives' xamna:k 'anxious' and tirsna:k 'fearful' are formed. The suffix -i: 'quality or state' can be attached to them to form the 'abstract nouns' xamna:ki 'anxiety' and tirsna:ki 'the fear' will be formed. Hence, the suffix $-n a: k$ can create 'adjectives' from the 'noun' and the root of the 'verb' and the nominal suffix $-i$ : can change the word class from an 'adjective' into 'abstract nouns'. The suffixes $-n a: k$ and $-i$ : can create new lexemes by multiple affixation. The second question addressed in the methodology section of this paper which is: Are the two languages capable of deriving new lexemes by the process of multiple affixation are answered and fulfilled through the above-mentioned discussion.

The derivational affixes have two main functions in both languages firstly, changing the grammatical categories of the original lexical items explained below, as well as the lexical meaning of the new derived lexemes. Standard English and Central Kurdish are similar in the derivational process of newly derived lexemes. In the category of nominal affixes, a 'verb' can be converted into a 'noun' by adding certain suffixes (see 3.2.1. Group 1 and 4.2.1. Group 1). Only in Kurdish, prefixes such as $\boldsymbol{b} \boldsymbol{i}$ - 'one who', $\boldsymbol{b} \boldsymbol{a}$ - 'quality of', $\boldsymbol{p e}$ - 'an instrument', $r a$ - 'a horizontal position', $d a-$ 'down' can be added to a 'verb' to form a 'noun' (see 4.2.1. Group 1). While no apparent prefixes contribute in the creation of new 'nouns' from 'verbs'.

In both languages, an 'adjective' can be converted into a 'noun' by attaching certain suffixes (see 3.2.1 Group 2, 4.2.1 Group 2). In Kurdish, the word class 'numerals' can be converted into a 'noun' by adding the suffix $-a$ (see 4 . 2. 1. Group 3), whereas in English, no newly derived lexemes can be formed by the 'numerals'.

In the category of adjectival affixes, in Standard English and Central Kurdish, certain suffixes can be attached to a 'noun' to form an 'adjective' and a 'verb' (see 3.2.2. Group 1 and 4.2.2. Group 1). For instance, in English, suffixes $-y$ and $-a w i$ 'covered with' in Kurdish could be attached to the 'nouns' cloud and hawr 'cloud', the adjectives 'cloudy and hawra:wi 'cloudy can be formed. More examples in English include the suffix able which is attached to a 'noun' like fashion, an 'adjective' fashionable is formed. The same suffix is added to a 'verb' such as achieve to form the 'adjective' achievable. The suffix -ic is attached to a 'noun' academy to form the 'adjective' academic and the same suffix could be attached to a 'verb' class to form the 'adjective' classic. In Kurdish, only the prefix $\boldsymbol{b} \boldsymbol{a}$ - 'abundance' can be attached to a 'noun' hez 'strength' to form an 'adjective' bahez 'strong' (see 4. 2. 2. Group 1). However, no prefixes can be attached to a 'noun' to form an 'adjective' in English. The adjectival affixes can also be formed by the suffixes $-\boldsymbol{y}$ in English and -ok 'characterized by' in Kurdish and they can be attached to the verbs 'anger' and larz 'shiver' to form the 'adjectives' angry and larzok 'shivering'. In Kurdish, a prefix such as $b a$ - can be attached to a 'verb' čež 'taste' to form the 'adjective' bačež 'tasty' (see 4.2.2, Group 2). According to the analysis of this paper, no noticeable prefixes will be attached to a 'verb' to form an 'adjective' in English.

In the category of verbal affixes, in English, a 'noun' can be converted into a 'verb' by adding certain prefixes and suffixes (see 3.2.3. Group 1). For instance, the suffix -ize can be attached to the 'noun' apology to form the 'verb' apologize, as well as the prefix en- can be attached to the 'noun' 'title' to form the 'verb' entitle.

In English, an 'adjective' can also be converted into a 'verb' by attaching certain suffixes (see 3. 2. 3. Group 2). For instance, the suffix -en when it is attached to the 'adjective' soft the 'verb' soften is formed. The prefix en'to cause to be' could be added to the 'adjective' large to form the 'verb' enlarge.

While in Kurdish, no newly derived verbs could be formed by attaching certain affixes. The reason can be attributed to the internal structure of Kurdish verbs that 
work into a different manner from English verbs. Thus, in the derivation of new lexemes from a 'verb', three main components must be considered: root, tense, person and number as shown in the example below:

$k r($ root $)+y a r($ suffix $)=$ krya:r 'buyer

$k r($ root $)+i$ (tense) $+-m$ (person and number $=k r i m$ 'I bought' $d a($ tense $)+k r($ root $)+m$ (person + number $)=$ 'I will buy $)$

$z a n($ root $)+i=z a: n i($ stem $)+-y a r=$ zanya:r 'scientist'

In the category of adverbial affixes, 'nouns' convert into 'adverbs' by adding some suffixes: -ward, -wards, wise, -ways and a prefix $a$ - as in ashore (see 3.2.4. Group 1). Moreover, 'adjectives' can be converted into an 'adverb' by affixing -ly (see 3.2.4 Group 2), whereas in Kurdish, no new lexemes could be formed by adverbial affixes.

In both languages, there are certain affixes that can be used in two or more-word classes. In English, for instance, the suffixes $-e e$, etc. can be added to the verb 'refer' and the adjective 'absent' to form the 'nouns' referee and absentee. In Kurdish, the suffix $-\boldsymbol{a}$ is attached to an 'adjective' čak 'virtue' a 'verb' qiž 'scream' and a 'numeral' sad 'hundred 'to form čaka 'virtuous', qi:ža 'screaming', as well as sada' a century'.

The first question addressed in the methodology section of this paper which is: Are class changing derivational affixes applicable in all the word classes in Standard English and Central Kurdish? are answered and fulfilled through the above-mentioned discussion with the addition that class changing derivational affixes in English could be attached to 'nouns', 'verbs', 'adjectives' and 'adverbs' while in Central Kurdish, they can only be attached to 'nouns', 'adjectives' and some 'numerals'.

\subsection{Findings}

In this paper, the following findings have been drawn:

1. In both languages, derivational affixes can change the grammatical categories and the lexical meaning of the base lexemes.

2. Class changing derivational affixes in Standard English could be attached to 'nouns', 'verbs', 'adjectives' and 'adverbs' while in Central Kurdish, they can only be attached to 'nouns', 'adjectives' and some 'numerals'.

3. In Standard English, a large number of new lexemes can be created by the process of multiple affixation. In Central Kurdish, new lexemes can be formed by the same process; however, the range of Kurdish examples is lesser than in English.

4. As far as the formation of newly derived lexemes is concerned, Standard English and Central Kurdish are similar in the formation of the nominal affixes, a 'verb' and an 'adjective' can be converted into a 'noun' by adding certain suffixes. Only Kurdish but not English can have prefixes that are attached to a 'verb' to form a 'noun'. Kurdish and English are different in that in Central Kurdish some 'cardinal numerals' can be converted into a 'noun' by attaching the suffix $\boldsymbol{- a}$ whereas in English, no newly derived lexemes can be formed by the numerals.

5. In the formation of the adjectival affixes, in Standard English and Central Kurdish, an 'adjective' can be formed by attaching certain suffixes to a 'noun' and a 'verb'. Only in Kurdish rather than English, certain prefixes can be attached to a 'noun' and a 'verb' to form an 'adjective'.

6. In English, in the formation of verbal affixes, a 'noun' and an 'adjective' can be converted into a 'verb' by adding certain prefixes and suffixes. While in Kurdish, no new lexemes can be formed from a 'noun' and an 'adjective' due to the difference in the internal structure of verbs in both languages.

7. In English, adverbial affixes can only be formed by attaching a prefix to a 'noun' and suffixes to a 'noun' and an 'adjective' to form adverbs. Whereas in Kurdish, no new adverbs are formed from nouns and adjectives.

8. In Standard English, the suffixes -ance -ness, -ish, $c y,-i s t,-a c y,-i s m,-d o m,-c e,-e e$ and in Central Kurdish, the suffixes -eti, -ča, -oka, -ala:n, -a, -ayi, $-i$ :, $-i n$ are all class-changing derivational suffixes that convert adjectives into nouns.

9. In Standard English, the suffixes $-a l,-y,-a b l e,-l y$, -ish, -ic, -ate, -ous, -ive, -ary, -ful and in Central Kurdish, the suffixes -awi, -a:ni, -a:na, -aki, -i:n, in, -ayi are class changing suffixes that convert nouns into adjectives.

10. In Standard English, the suffixes - ive, able, -ible, -,dom, -less, -ory -able, -ent, $-y,-i c$ are all class changing suffixes that convert verbs into adjectives.

11. In Standard English, the suffixes -ify, -ize and the prefix be-, en- are all class-changing derivational affixes that convert nouns into verbs.

12. In Central Kurdish, the prefixes $b i-, b a-, p e-, r a:, d a$ are class changing derivational affixes that convert verbs into nouns.

\section{REFERENCES}

Akmajian, A., Demers, R. A., Harnish, R. M. and Farmer, A. K. (2001). Linguistics: An Introduction to Language and Communication. (5thed.). Cambridge: MIT Press.

Aronoff, M., and Fudeman, K. (2011). What is Morphology? (2nd ed.). Malden, MA: Wiley-Blackwell.

Awl, M. O. (2010) Dabešûnî Kirdarî Lêkiraw Le Ŕwî Daŕištinw Erkewe \{Classification of Compounding Verbs from the Compositional and Functional Perspectives\}. Journal of Kurdology. Sulaimani. Kurdology.

Baban, Š. (2008) Beraw Wiša Ŕonan le Zimanî Nwsînda \{towards Derivational Words in Written Language\}. Hewler: Aras Publishing House.

Bakir, A. and Awl, M. (2012), Durstai Nawawai Nawi Nasa:da La Dyalekti Kirmanji Nawarastda \{The Internal Structure of Non- 
Simple Nouns in the Central Kurdish Dialects\}, Al Ustath Journal, No 102, College of Education, Ibn Rushd, University of Baghdad, Baghdad.

Bauer, L. (1983). English Word-Formation. Edinburgh, UK: Cambridge University Press.

Brinton, L. J., and Brinton, D.M. (2010) The Linguistic Structure of Modern English. John Benjamins Publishing Company.

Clark, V., Hecht, B., and Mulford, R. (1986). Acquiring Complex Compounds: Affixes and Word Order in English. Linguistics 24, 7-29.

Dizayee, A. M. (2012). Wišasazî Zimanî Kurdî \{Kurdish Morphology\}. Hewler: University of Salahaddin.

Dupanović, E., (2019). Class-Changing Prefixes in the English Language, DHS2 (8) (2019), 73-88

Fatah, A., Hamawand, Z. A. (2014). Prototype Approach to Kurdish Prefixes, International Journal on Studies in English Language and Literature (IJSELL)

Volume2, Issue10, October2014, PP37-49ISSN 2347-3126 (Print) \& ISSN 2347-3134(Online)

Fattah, A. H. (2012) A Cognitive Grammar Analysis of Suffixes in English and Kurdish. University of Sulaimani, Published PhD dissertation.

Fattah, M. M. and Qadir, S. R. (2006) ĉend Layeněkî Morfologî kurdî \{Some Aspects of Kurdish Morphology\}. Sualeimanî: Rûn Press house.

Hamawandy, A. (2012). Derivational Morphemes in English with Reference to Dialects in Kurdish: A Comparative Analysis. Kirkuk University Journal- HumanityStudies Vol:7 No:3.

Hornby, A., Turnbull, J., Ashby, M., Lea, D., Parkinson, D., Phillips, P., Francis, B., Webb, S. and Bull, V., (2015). Oxford Advanced Learner's Dictionary of Current English. (9th ed.). Oxford: Oxford University Press.

Katamba,F. (1993). Morphology. The Macmillan Press Ltd. London.

Katamba,F., and Stonham, J. (2006). Morphology. (2nd ed.). Pa lgrave Macmillan Ltd.

Leningrad, A. (1986). Lexicology of the modern English language. (3rd ed.). Moscow Higher School. BBK 81.2 Eng-923 A 84

Marif, A. (1977) Wiša Ŕonan le Zimanî Kûrdîda (Word Forma tion in the Kurdish Language). Baghdad: Kurdish Academic Press.

Marif, A. (2014) Wiša Ŕonan le Zimanî Kûrdîda (Word Forma tion in the Kurdish Language). Hewler: Ŕojhalat Publishing House.

McCarthy, C. (2002). An Introduction to English Morphology: Word s and Their Structure. Edinburgh: Edinburgh University Press.

Muhammad, M. (2011). Zarawasazî Pêwana \{Measure Terminology\}. (2nd ed.) Hewler: Aras Publishing House.

O'Grady, W., and Archibald, J. (2016). Contemporary Linguistic Analysis: An Introduction. (8th ed.). Toronto: Pearson.

Qazzaz, S. (2000) The Sharezoor Kurdish-English Dictionary. Erbil: Aras Press and publisher.

Radford, A., Atkinson, M., Britain, D., Clahsen, H., and Spencer, A. (2009). Linguistics: An Introduction. (2nd ed.). Cambridge: Cambridge University Press.

Rowe, B.M., Levin, D.P. (2016). A Concise Introduction to Linguistics. (4thed.). London and New York: Routledge.
Somathasan, M. (2018). The study of affixes (prefixes and suffixes): An ESL and innovative approach. IJAR, pdfs.semanticscholar.org

Stageberg, N. C. (1981). An Introductory English Grammar. (4th ed.). USA: University of Northern Iowa.

The Kurdish Academy Journal. (1975). Language and Linguistic Terms. (Zmanu Zanstakani). Vol. (3), No (1), 1975.Baghd ad: The Kurdish Academy Press.

Yule, G. (2010). The Study of Language. (4th ed.). New York: Cambridge University Press. 